\title{
Spatial analysis, temporal trend, and local risk of congenital syphilis new cases in Sergipe, Brazil
}

Análise espacial, tendência temporal e risco local de novos casos de sífilis congênita em Sergipe, Brasil

\author{
K. B. da Silveira1' J. R. S. Silva ${ }^{1}$; F. P. Reis ${ }^{2}$; A. D. dos Santos ${ }^{3}$; K. C. G. M. de \\ Araújo $^{1,4}$; I. F. L. de Melo"; T. G. dos Santos ${ }^{4}$; V. L. C. Feitosa ${ }^{1,4^{*}}$

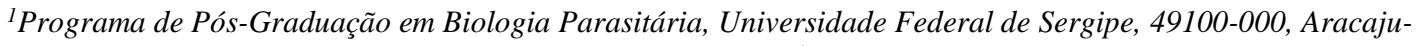 \\ Sergipe, Brazil \\ ${ }^{2}$ Programa de Pós-Graduação em Saúde e Ambiente, Universidade Tiradentes, 49010-390, Aracaju-Sergipe, Brazil \\ ${ }^{3}$ Departamento de Enfermagem, Universidade Federal de Sergipe, 49400-000, Lagarto-Sergipe, Brazil \\ ${ }^{4}$ Departamento de Morfologia, Universidade Federal de Sergipe, 49100-000, Aracaju-Sergipe, Brazil
}

*vera_feitosa@uol.com.br

(Recebido em 20 de julho de 2020; aceito em 09 e novembro de 2020)

\begin{abstract}
The present study aimed to analyze the spatial distribution and its temporal trend, and to identify areas of risk for the occurrence of congenital syphilis in Sergipe, Northeastern Brazil. An ecological study of time series and spatial analysis techniques was performed, with municipalities as units of analysis. Data were obtained from the Notifiable Diseases Information System and included all cases of congenital syphilis reported from 2007 to 2015 in Sergipe. The local empirical Bayesian method used to minimize the rate variance. Spatial autocorrelation was used to analyze spatial patterns. 2,381 new cases of congenital syphilis were recorded in the studied period. A unique trend was found to increase the incidence, ranging from 2.7 (2007) to 11 (2015) per 1,000 live births. The average incidence in the period was 7.63 cases per 1,000 live births. Moran's global index was $I=0.64(p<0.01)$, indicating the existence of spatial dependence; the Moran map identified 20 municipalities as priority areas of attention in Sergipe. There was a tendency to increase the incidence of congenital syphilis during the study period (2007-2010). As of 2010, the disease continued to grow, but with less growth than in previous years. As of 2011, there was stabilization with a remaining incidence of around 11 cases per 1,000 live births until 2015. The geographical distribution of the risk areas was heterogeneous, both due to the breadth of the territory and the concentration of cases in some regions.

Keywords: congenital syphilis, Epidemiology, spatial analysis
\end{abstract}

O presente objetivou analisar a distribuição espacial e sua tendência temporal, e identificar áreas de risco para a ocorrência de sífilis congênita em Sergipe, Nordeste do Brasil. Foi realizado um estudo ecológico de séries temporais e com técnicas de análise espacial, tendo os municípios como unidades de análise. Os dados foram obtidos no Sistema de Informação de Agravos de Notificações e incluíram todos os casos de sífilis congênita notificados de 2007 a $2015 \mathrm{em}$ Sergipe. O método bayesiano empírico local usado para minimizar a variância da taxa. A autocorrelação espacial foi usada para analisar os padrões espaciais. Foram registrados 2.381 casos novos de sífilis congênita no período estudado. Foi encontrada uma tendência única de crescimento da incidência, variando de 2,7 (2007) a 11 (2015) por 1.000 nascidos vivos. A incidência média no período foi de 7,63 casos por 1.000 nascidos vivos. O índice global de Moran foi $I=0,64(p<0,01)$, indicando a existência de dependência espacial; o mapa Moran identificou 20 municípios como áreas prioritárias de atenção em Sergipe. Houve uma tendência de aumento da incidência de sífilis congênita durante o período de estudo (2007-2010). A partir de 2010 a doença continuou a crescer, mas com menor intensidade de crescimento em relação aos anos anteriores. A partir de 2011, houve estabilização com uma incidência remanescente em torno de 11 casos por 1.000 nascidos vivos até 2015. A distribuição geográfica das áreas de risco era heterogênea, tanto pela amplitude do território quanto pela concentração de casos em algumas regiões.

Palavras-chave: sífilis congênita, Epidemiologia, análise espacial 


\section{INTRODUCTION}

According to the World Health Organization (WHO), 930,000 women acquire gestational syphilis annually, of which approximately 350,000 will transmit the disease to the fetus through the placenta. More than half of these fetuses will develop several adverse effects, such as organ deformities, prematurity, and neonatal death, which reinforces the international commitment to eliminate syphilis as a public health problem $[1,2]$. Congenital syphilis continues to be a preventable cause of global stillbirth and neonatal morbidity and mortality [3].

Japan has experienced a rapid increase in syphilis in women of reproductive age in recent years [4]; about 12,000 newborns contract congenital syphilis each year. In Brazil, among the difficulties to control the disease are the late diagnosis and lack of women-focused care, which provides a risk of reinfection by untreated partners, indicating a possible inadequate performance of prenatal follow-up [5].

In 2007 the WHO proposed a global initiative to eliminate congenital syphilis in three regions: the Americas, Asia-Pacific, and Africa. These continents have initiated efforts focused on maternal and fetal double elimination of HIV and syphilis transmission, aiming to improve maternal and child health and contributing to the achievement of Millennium Development Goals. Thus, validation criteria were established in these locations to reach these goals, in which $95 \%$ of pregnant women would undergo prenatal exams, HIV and syphilis testing, and those diagnosed with HIV or syphilis would receive treatment. For fetal transmission, targets were as follows: for HIV, $\leq 50$ new pediatric infections per 100,000 live births and a transmission rate of $<5 \%$ in women who are breastfeeding; and for syphilis, $\leq 50$ cases of congenital syphilis per 100,000 live births [6, 7, 8 ].

Syphilis, which is caused by the spirochete Treponema pallidum, continues to be a global incident disease, despite remaining susceptible to penicillin treatment. Syphilis vaccine development is a viable preventative approach that will serve to complement public health-oriented syphilis prevention [9]. In Brazil, all forms of syphilis-acquired, gestational, and congenital-require notification. In the gestational form, the estimate is that, annually, about two million pregnant women are infected worldwide for not being adequately diagnosed and treated. This situation happens mainly in South Africa, where approximately $63 \%$ of pregnant women are infected. Due to this fact, the interest of world authorities in syphilis control has increased, since $70 \%$ of untreated or inadequately treated pregnant women transmit the infection to the fetus, causing congenital syphilis [10].

Although in Sergipe, a state from northeast Brazil, the disease is considered a priority in its epidemiological surveillance programs, studies focused on this subject are still scarce. Therefore, studies indicating the cities more incident to the disease, as well as possible causes that increase the problem, are necessary. Such data may contribute to future improvements in preventive and curative actions. Geoprocessing to evaluate the incidence of congenital syphilis is an important tool for managers, professionals, and researchers, enabling them to identify the disease clustering and verify its spatial distribution. Thus, prevention strategies for elimination in the transmission chain can be performed in an equitable manner and directed at risk areas [11].

This study aimed to analyze the spatial distribution and its temporal trend, as well as identify the local risk areas of congenital syphilis occurrence in Sergipe, Brazil.

\section{METHODS}

\subsection{Study Area}

The present study was performed in the state of Sergipe (Figure 1), located in the northeastern region of Brazil. The total area of the state is $21,918,493 \mathrm{~km}^{2}, 0.26 \%$ of the total national area. It is composed of 75 municipalities, according to the Instituto Brasileiro de Geografia e Estatística (IBGE) [12]. In 2017, the IBGE estimated a population of 2,288,116 inhabitants in Sergipe, with a population density of 94.36 inhabitants $/ \mathrm{km}^{2}$ and a life expectancy at birth of 72.4 years. The general climate in the state is semi-arid, consisting of 7 to 11 dry months [12]. 


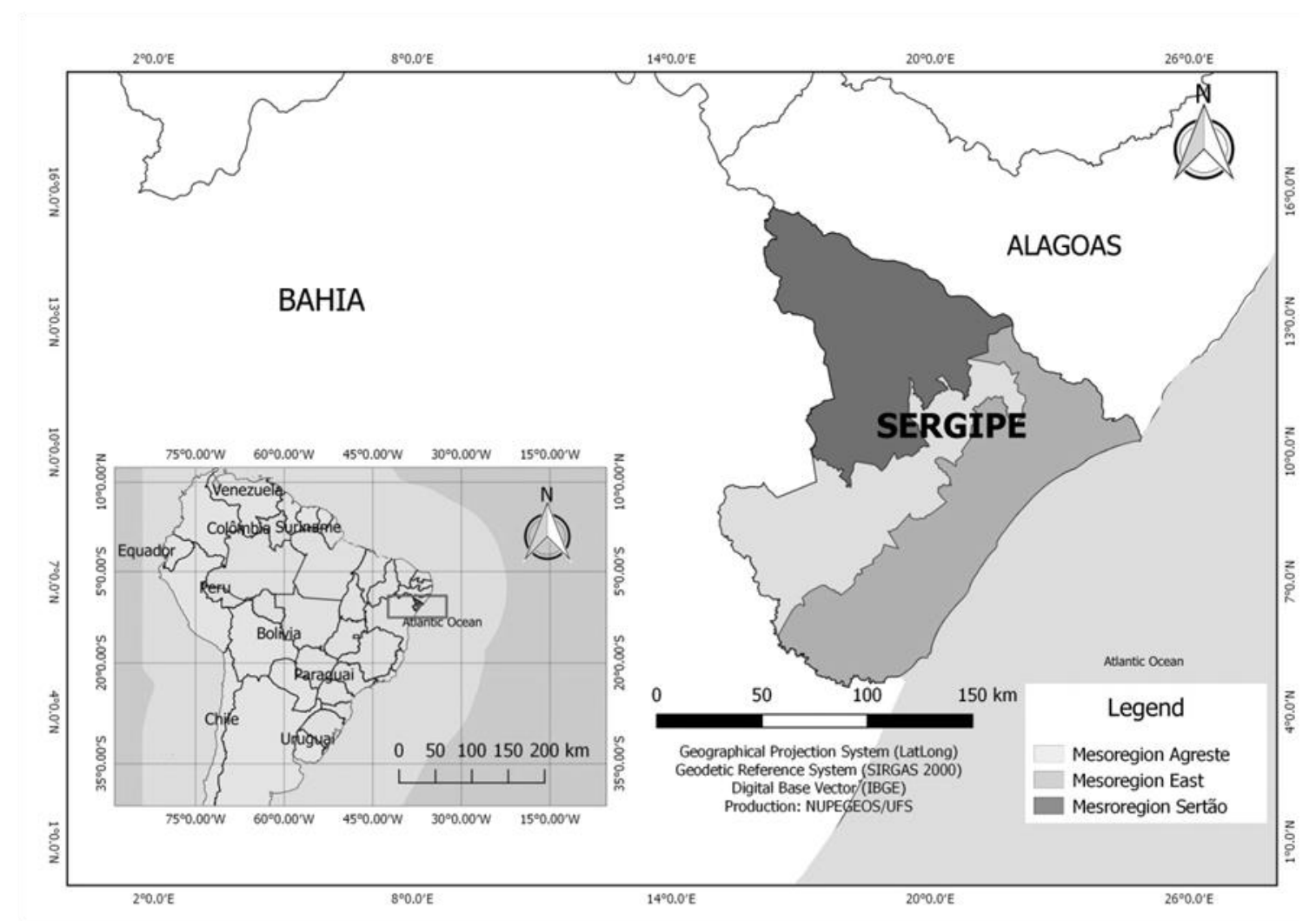

Figure 1: Geographic location of the state of Sergipe, Brazil, and its division into Mesoregions.

\subsection{Study design, population, and data sources}

A mixed ecological study was performed using temporal and spatial analysis techniques as well as secondary data from congenital syphilis notifications in Sergipe between 2007 and 2015. The analysis units were the state's 75 municipalities.

The definition of congenital syphilis was based on the following criteria: 1) any child, abortion, or stillbirth from a woman with clinical or serological evidence for syphilis that has not been treated or has received inadequate treatment; 2) children under 13 years of age with serological evidence for syphilis, once chances of maternal antibodies maintenance and acquired syphilis were excluded; 3) children under 13 years of age with non-treponemic serology for syphilis and clinical, radiological, or cerebrospinal fluid (CSF) evidence for congenital syphilis; or 4) microbiological evidence of Treponema pallidum in the placenta, umbilical cord, or child tissue from abortion or stillbirth [13].

Data were from the public domain and comprised all confirmed new cases of congenital syphilis, considering the International Classification of Diseases 10th revision (ICD-10). Epidemiological indicators were described with annual incidence rates, from the ratio between the number of new cases of congenital syphilis and live births, living in the same place and period considered, and multiplied by the constant 1,000. Data were obtained directly from Sistema de Informação de Agravos de Notificação (SINAN) and Sistema de Informação de Nascidos Vivos (SINASC) for Sergipe. Cases presenting diagnostic errors, duplication, inconsistency, or incompleteness in the files were excluded from the study. Population data and cartographic grids were obtained from the IBGE [12].

\subsection{Statistical analysis}

To adjust the incidence time trends, non-linear regression was also performed, using the following formula: 


$$
\text { Incidence }=\frac{a}{1+\mathrm{e}^{-r \times(\text { Year }-L)}}
$$

The model choice was based on the observation of the series scatterplot. In the model, a represents the curve threshold was adjusted, $r$ indicates the direction and magnitude of the time trend, and L is the curve inflection point. The parameters were estimated using the LevembergMarquard algorithm, and a 95\% confidence level was considered in the calculation of the confidence interval.

The cartographic base of Sergipe was used, available in the IBGE electronic base [14]. The cartographic projection corresponded to the SIRGAS 2000 Universal Reference System. The Bayesian estimator was used to minimize the instability caused by the cases' random fluctuation, smoothing the standardized rates by applying weighted averages and creating a third corrected rate $[15,16]$. The Empirical Bayesian Rate illustrated a correction of the multiplicative rate equal to 1,000 , considering the population at risk and the number of cases for each year analyzed, by municipality.

The spatial autocorrelation between incidence rates was used to investigate whether the disease spatial distribution would occur randomly or followed some occurrence pattern in space. A spatial proximity matrix was elaborated using the nearest neighbor criteria, with a 5\% level of significance and calculating the Moran Global Index (I) [17] varying between -1 and +1 , which represents the expression of spatial autocorrelation of congenital syphilis incidence in the geographic space analyzed to identify spatial clusters and define risk areas. Values close to 0 indicate spatial randomness, between 0 and +1 positive spatial autocorrelation, and between -1 and 0 negative spatial autocorrelation.

A significance level of 5\% was adopted throughout the study, and all statistical analyses were performed in R software (Version 3.5.0).

\subsection{Ethical aspects}

The study was approved by the Human Research Ethics Committee of the Universidade Federal de Sergipe, Brazil (registration no. 65892316.6.0000.5546).

\section{RESULTS AND DISCUSSIONS}

In Sergipe, from 2007 to 2015, 2,381 new cases of congenital syphilis were reported in SINAN. The mean incidence for the period was 7.63 cases per 1,000 live births, ranging from 2.68 (2007) to 11.0 (2015) per 1,000 live births. Therefore, there was a growing and significant trend of congenital syphilis incidence rates in the state.

The temporal trend of the disease, per year, was constructed through the general incidence of congenital syphilis in Sergipe. In Figure 2 it is possible to observe that the disease had an upward curve, thus indicating an increasing trend, whereas from 2010, although the disease continued to grow when compared to previous years, it had lower growth intensity. From 2011 to 2015, there was a trend towards stabilization, with the incidence remaining around 11 cases per 1,000 live births. 


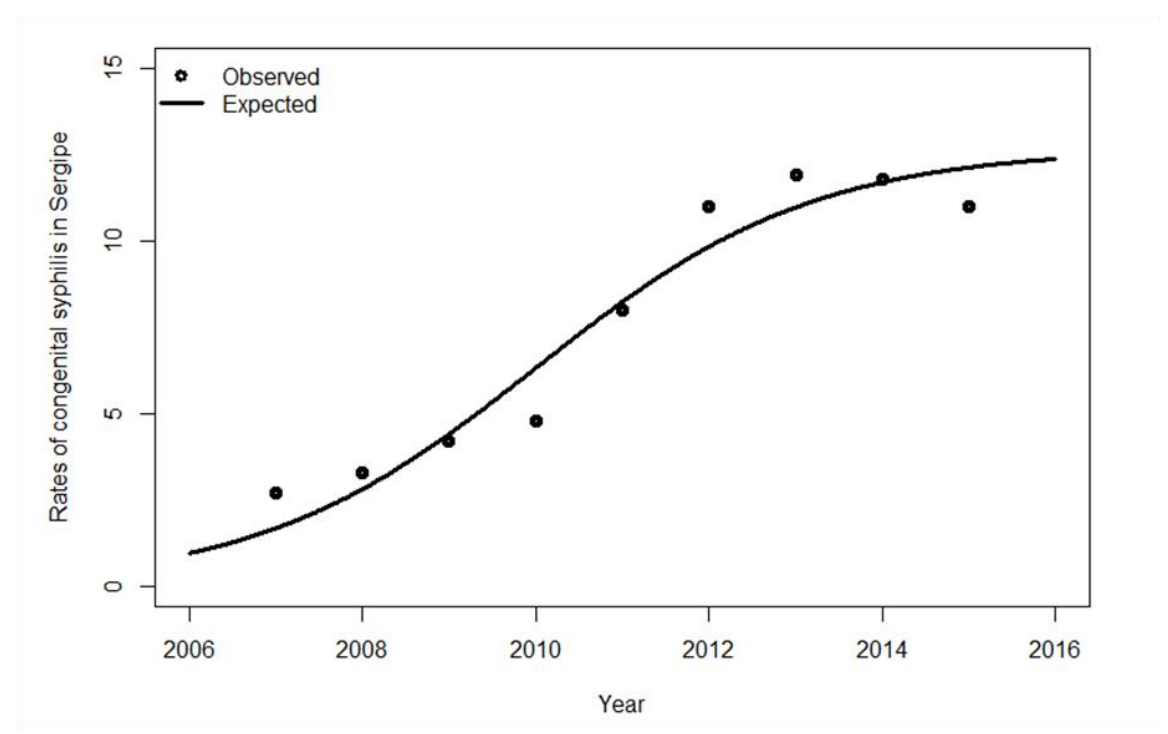

Figure 2: Temporal trend of Congenital Syphilis incidence in Sergipe, Brazil, from 2007 to 2015.

To model the syphilis incidence trend per 1,000 live births, a non-linear regression adjustment was used, according to the data presented in Table 1. The adjusted model showed that the series was increasing $(r=0.62 ; \mathrm{p}<0.01)$, that is, there was an increasing curve of incidence for the disease over the period studied, characterized by the parameter sign. When $r$ is positive, the curve under analysis is increasing. It is also noted that the incidence growth starts to decelerate from 2010 on, as indicated by the parameter $\mathrm{L}=2,010.01(\mathrm{p}<0.01)$, meaning that the trend of syphilis incidence began to lose strength, until the curve stabilized in 2012. This stabilization occurred when the case incidence reached $a=12.67(\mathrm{p}<0.001)$ per 1,000 live births. From 2012 to 2016, the disease incidence continued around this value.

Table 1: Trend evaluation of Congenital Syphilis incidence in Sergipe, Brazil, from 2007 to 2015.

\begin{tabular}{cccccc}
\hline \multirow{2}{*}{ Parameter } & \multirow{2}{*}{ Estimate } & \multirow{2}{*}{ Standard Deviation } & \multicolumn{2}{c}{ Confidence Limit (95\%) } & \multirow{2}{*}{ P value } \\
\cline { 4 - 5 } & & & Lower & Upper & \\
\hline $\boldsymbol{a}$ & 12.67 & 1.29 & 9.69 & 15.64 & $<0.01$ \\
$\boldsymbol{r}$ & 0.62 & 0.17 & 0.24 & 1.00 & $<0.01$ \\
$\boldsymbol{L}$ & $2,010.01$ & 0.52 & $2,008.80$ & $2,011.22$ & $<0.01$ \\
\hline
\end{tabular}

Table 2 shows the Moran Index calculated for incidences and Bayesian rates. Moran's general index was positive and significant $(I=0.64, p<0.01)$, indicating spatial dependence. Through this indicator, it was evidenced that municipalities of high incidence tended to be neighbors of municipalities with high incidence, and, in the same way, municipalities characterized by low incidence were likely to be close to other municipalities with low incidence.

On average, for each neighbor considered in the analysis, the Moran Index decreased 0.04 $(\mathrm{p}<0.01)$ for the incidence. In percentage terms, this index decreased, on average, $11.18 \%$ for each neighbor added in the incidence analysis. That is, for each municipality added in the group, the force of influence between the municipalities of the group decreased $11.18 \%$, reinforcing the idea regarding the association strength of congenital syphilis presence among nearby municipalities, as well as the idea of the disease spatial dependence.

Table 2 also points out, through the Moran Index calculation, the measure of incidence according to the closest neighbor. In this way, random fluctuation failures were reduced. The estimator (Bayesian) showed the same behavior as that previously calculated by the Moran Index: for each additional neighbor added to the group, the disease association strength decreased by 0.07 ( $<<0.01)$. In percentage terms, for each municipality added to the analysis group, the correlation decreased 
from $14.16 \%$, reinforcing the idea that the greater the proximity between the municipalities with high incidence, the greater the disease influence force between the studied groups.

Table 2: Moran Index for the incidence per 1,000 live births and for the Bayesian empirical rate observed in Sergipe, from 2007 to 2015.

\begin{tabular}{ccccc}
\hline \multirow{2}{*}{ Number of neighbors } & \multicolumn{5}{c}{ Moran Index } \\
\cline { 2 - 5 } & Incidence & $\mathbf{P}$ & Bayesian empirical rate & P \\
\hline 1 & 0.64 & $<0.01$ & 0.91 & $<0.01$ \\
2 & 0.50 & $<0.01$ & 0.71 & $<0.01$ \\
3 & 0.42 & $<0.01$ & 0.59 & $<0.01$ \\
4 & 0.38 & $<0.01$ & 0.50 & $<0.01$ \\
5 & 0.33 & $<0.01$ & 0.42 & $<0.01$ \\
6 & 0.26 & $<0.01$ & 0.33 & $<0.01$ \\
7 & 0.26 & $<0.01$ & 0.31 & $<0.01$ \\
8 & 0.24 & $<0.01$ & 0.28 & $<0.01$ \\
9 & 0.23 & $<0.01$ & 0.26 & $<0.01$ \\
10 & 0.24 & $<0.01$ & 0.27 & $<0.01$ \\
\hline
\end{tabular}

In the stratification of incidence, a total of 18 municipalities (24\%) had rates above nine cases per 1,000 live births; 20 municipalities $(26.6 \%)$ had rates ranging from 6 to 8.99 cases per 1,000 live births; 27 municipalities (36\%) had rates ranging from 3 to 5.99 cases per 1,000 live births; and 10 municipalities (13\%) had rates lower than three cases per 1,000 live births (Figure 3A). Figure $3 \mathrm{~A}$ also shows, in the map clusters, the 17 municipalities with higher incidence of the disease, distributed in descending order of incidence: Campo do Brito, Riachuelo, Divina Pastora, Barra dos Coqueiros, Nossa Senhora das Dores, Rosário do Catete, Macambira e Nossa Senhora do Socorro, Malhada dos Bois, Arauá, General Maynard, Estância, Capela, Muribeca, Siriri, Aquidabã, São Cristóvão, and Umbaúba. All of these municipalities had an average incidence of nine cases per 1,000 live births over the years studied and were considered priority areas of special attention. This high incidence of congenital syphilis was distributed in the northeast, centraleastern, and southern regions of Sergipe. From these regions, the lowest intensity of congenital syphilis infection was found in the southern region.

In 20 municipalities, incidences ranging from 6 to 8.99 cases per 1,000 births were found, in descending order: Pedrinhas, Itabaiana, Santa Rosa de Lima, Laranjeiras, Feira Nova, Carmópolis, Tomar do Geru, São Miguel do Aleixo, Areia Branca, Japaratuba, Santo Amaro das Brotas, Boquim, Pirambu, Aracaju, Cristinápolis, Maruim, Gracho Cardoso, Itabaianinha, Propriá, and Japoatã.
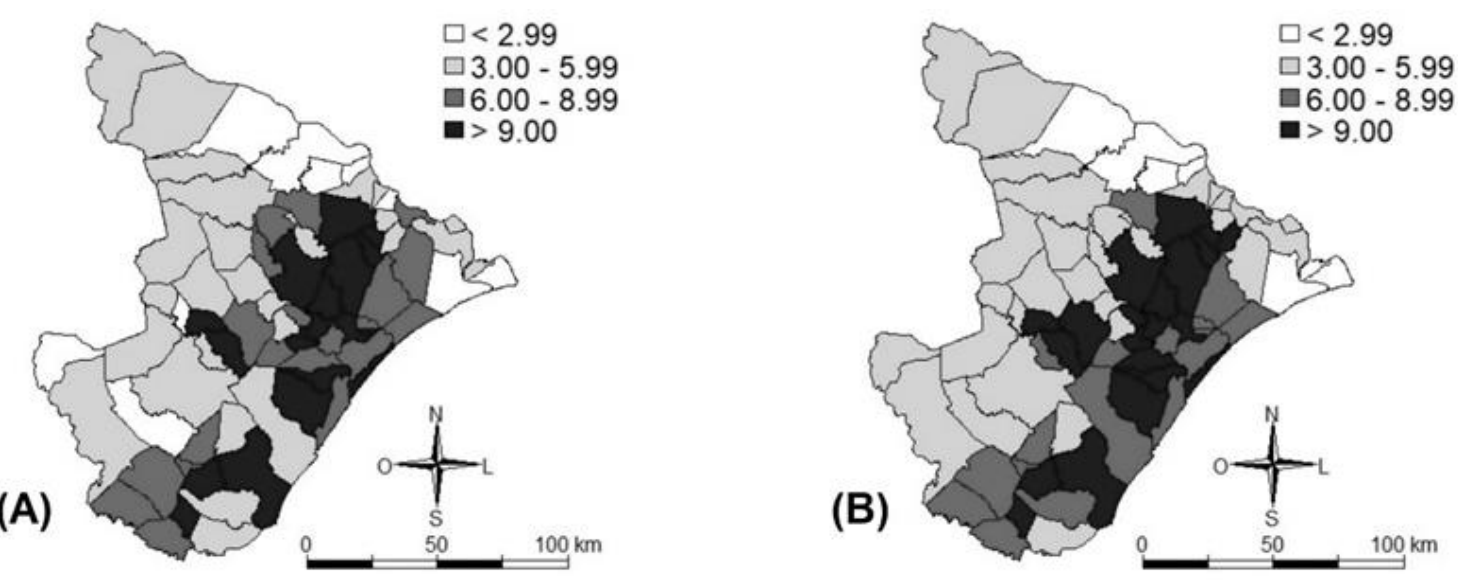

Figure 3: (A) Spatial analysis on the general incidence for new cases of Congenital Syphilis: incidence for new cases in Sergipe, Brazil, from 2007 to 2015. (B) Rate smoothed using the local empirical Bayes method in Sergipe, Brazil, from 2007 to 2015. 
In 27 municipalities, the incidence varied from 3 to 5.99 cases per 1,000 live births, in descending order: Canhoba, Amparo de São Francisco, Frei Paulo, Indiaroba, Itaporanga d'Ajuda, Lagarto, Tobias Barreto, Salgado, São Domingos, Monte Alegre, Nossa Senhora Aparecida, Malhador, Santana do São Francisco, Pinhão, São Francisco, Neópolis, Santa Luzia do Itanhy, Cedro de São João, Cumbe, Carira, Poço Redondo, Canindé de São Francisco, Moita Bonita, Nossa Senhora da Glória, Ilha das Flores, Simão Dias, and Ribeirópolis. Meanwhile, 10 municipalities had incidences lower than 2.99 cases per 1,000 live births: Pacatuba, Porto da Folha, Riachão do Dantas, Nossa Senhora de Lourdes, Telha, Poço Verde, Itabi, Brejo Grande, Gararu, and Pedra Mole.

The local empirical Bayesian estimator (Figure 3B) included spatial effects, calculating the estimate locally using only the geographic neighbors of the area in which the rate was estimated, leading to convergence towards a local average instead of an overall one. Corrected rates were more stable, since they considered not only the area information but also the information of the neighborhood [18].

The map in Figure 3B shows municipalities with an incidence greater than nine cases per 1,000 live births, being ordered according to their incidence: Campo do Brito, Riachuelo, Divina Pastora, Barra dos Coqueiros, Nossa Senhora das Dores, Nossa Senhora do Rosário do Catete, Macambira, Malhada dos Bois, Nossa Senhora do Socorro, Arauá, Estancia, Capela, Muribeca, Siriri, Aquidabã, Umbaúba, São Cristóvão, Itabaiana, Santa Rosa de Lima, and Laranjeiras. The municipalities São Francisco, Laranjeiras, and Santa Rosa de Lima had minor incidence, being classified among the municipalities considered of highest incidence due to their geographic proximity to those with high incidence. Due to the calculation of the area global average, the municipality General Maynard did not fit into this category of municipalities distribution map, even though it had a high incidence.

\section{DISCUSSION}

Epidemiological data were presented in this study, showing the municipalities and regions most affected by congenital syphilis in the state of Sergipe, Brazil. Congenital syphilis incidence increased from 2.68 in 2007 to 11 cases per 1,000 live births in 2015. The mean incidence was 7.63 cases per 1,000 live births, higher than that recommended by the Ministério da Saúde $(0.5$ cases per 1,000 live births) [19]. Among pregnant women in this period, $75.8 \%$ received prenatal care yet still transmitted syphilis to their children.

In Sergipe, there was a considerable increase in the number of reported cases of congenital syphilis, and the disease had a trend to grow over the studied years $(r=0.62)$. By 2010, the disease growth rate was greater than in subsequent years. Still, as of 2011, the disease incidence began to decelerate, with a trend towards stabilization, although the incidence rate remained high.

In a study carried out by Saab and Tomaz (2016) [20] in order to know the prevalence, the occurrence of abortion, and the age of pregnant women with syphilis infection in Sergipe, it was concluded that the abortion record was high in pregnant women in most municipalities. The prevalence rates and incidence of syphilis were higher than those recommended by the WHO, and syphilis may be a factor associated with the occurrence of high incidence of abortion and perinatal morbidity and mortality.

A prospective, observational study about the adherence and follow-up of newborns of mothers with positive serology for Treponema pallidum, conducted at the Philanthropic Maternity of Aracaju between 2010 and 2014, showed an average incidence of 10.2 cases per 1,000 live births. Additionally, $28 \%$ of the newborns did not attend the first consultation for treatment of the disease, the treatment abandonment rate was $75 \%$, and the mean cure rate of these newborns was 2.25 months. The high incidence of syphilis was associated with low adherence to treatment, as only $67.1 \%$ of newborns were treated with crystalline penicillin [21]. In countries such as China, it has been recommended to use two doses of benzathine penicillin in the first and third quarters, respectively. Meanwhile, in some countries with high occurrence of congenital syphilis, a shortage of penicillin has been reported [22].

In the state of Amazonas (northern of Brazil), from 2007 to 2009, the detection rate of gestational syphilis ranged around 2 cases / 1000 live births. In 252 (51.9\%) cases, notifications of diagnosis of maternal syphilis occurred late, as in $144(29.6 \%)$, diagnostic occurred during prenatal care. 
Only $17 \%$ of women were treated properly. Less than a quarter of the partners of these mothers were treated [23]. In the state of Alagoas (northeast of Brazil), between 2007 and 2011, in a study that associated the presence of syphilis infection in pregnant women and sociodemographic data, a detection rate of 4.58 thousand cases / live births was found. Infected pregnant women, mostly of color were the brown and black skin, low education, and not more than 29 years of age. Reportedly only $68.4 \%$ attended the prenatal units and few were diagnosed in prenatal care $(25.6 \%)$ and half were diagnosed with the disease carried out during delivery / curettage (50.2\%). On the other hand, $85 \%$ of patients were untreated or inadequately treated syphilis and for the majority of its partners had not received any type of treatment $(65.8 \%)$. The mortality rate during this period was $10.2 \%$ [24].

An epidemiological analysis on congenital syphilis was carried out by Catunda et al. (2013) [25] in the state of Ceará (northeast of Brazil), from 2007 to 2010. Among 1132 women, 71.78\%, of their children had congenital syphilis infection, underwent prenatal care and access to diagnostic tests, and occurred only during delivery or curettage. Most of its partners held no treatment and the children were diagnosed in the recent form of the disease, i.e., in the maternity [25].

Despite the expansion of perinatal care in Brazil in recent years, the incidence of congenital syphilis in Sergipe has been very high. However, the marked differences in the magnitude of this morbidity indicate that, at least, the improvements implemented have not produced the expected breakthroughs. With the implementation of "Rede Cegonha," there has been an increase in the number of actions directed to women from prenatal, childbirth, and puerperium caring, with the availability of rapid tests in both the basic health units and reference hospitals, to their childbirth, with coverage of actions directed to the child's first two years of life throughout Brazil in Sistema Único de Saúde (SUS). Thus, there was stabilization in the growth rate of congenital syphilis [26], as observed in Sergipe.

According to the WHO, more than 12 million cases of syphilis are diagnosed annually worldwide, with a higher incidence in countries considered as "poor." The disease presence in pregnant women is associated with 90,000 neonatal deaths and 65,000 pre-term deliveries or lowbirth-weight infants, with overall rates for adverse events ranging from 58 to over 80 [27]. In the US, congenital syphilis affects, especially in the south of the country, women of ethnic and racial minorities. On the other hand, despite the cheapness and availability of prevention through screening and treatment of pregnant women, the cases of the disease continue to increase, with emphasis on its concentration in a few counties and US states [28].

Recent data on gestational and congenital syphilis in Brazil were alarming. A significant proportion of women and newborns were infected, with a $104 \%$ increase in syphilis among pregnant women between 2005 and 2013. During the same period, there was a 135\% increase in congenital syphilis reports, which may be related to both the increase in notifications and the improvement in health information services [29]. Although improvement actions were beneficial, they were not sufficient to explain the epidemic of reported cases, in both women and children, in this context [29].

A national historical study was carried out between 2007 and 2017 to analyze the trend and regional distribution of syphilis in Brazil. In 2017, 119,800 cases of acquired syphilis were reported, which meant a rate of 58.1 cases per 100,000 inhabitants, considered to be very high. The rate of acquired syphilis increased from 12.3 cases per 100 thousand inhabitants in 2011, to 81.4 in 2017, which represented a gross growth rate of $561 \%$. The detection rate of gestational syphilis went from 2.2 / 100 thousand inhabitants in 2007 to 16.9 in 2017, which meant a gross growth rate of $660 \%$. Meanwhile, congenital syphilis had increased from a rate of 2.00/1,000 live births in 2007 to 8.8 2017 (gross growth rate of 338\%). Numbers considered too high for national parameters [30].

While interpreting this study's results, some issues need to be considered, especially concerning data quality, such as underreporting, incorrect and incomplete filling of some fields on the notification form, and errors in the disease classification (recent and late congenital syphilis). In addition, since this is an ecological study, aggregated areas were subject to scale effects or area aggregation, as well as difficulties in defining the geographical boundaries of each area, which may interfere in the results. It is possible that the results were affected by statistical bias with the option of using smoothed rates. However, such rates have been used as strategies to overcome the instability of rates produced by a small number of observations found in small areas. 
Nevertheless, the present findings leave no doubt about the need to offer differentiated prenatal, childbirth, and puerperium assistance for Sergipe municipalities in order to stimulate the development of adequate supervision in higher-risk areas for congenital syphilis in the state. Screening for syphilis infection in pregnant women is associated with a reduction in the incidence of congenital syphilis, and available evidence supports the need for more emphatic actions directed towards positive test results [31]. The achievement of these objectives requires constant vigilance in these areas, adequate access to care by qualified professionals, and the implementation of public policies focused on social fairness, since they can minimize the adverse effects of disadvantaged positions in the social space.

The performance of quick tests for HIV and syphilis during prenatal care, instituted by "Rede Cegonha," is of great importance in this context. In most gestational syphilis cases, patients are not aware of the disease, and it is through quick testing that they acquire knowledge about it [32]. In these cases, the disease is in a latent stage, when symptoms do not develop, and the test is necessary for both diagnosis and targeting of therapeutic actions [32].

The knowledge of basic care professionals about syphilis in all its presentations - acquired, gestational, and congenital - is an important factor in the control and cure of this disease. A crosssectional study conducted by Rodrigues between January and May 2015 on the knowledge management and practices of health professionals working on prenatal care on syphilis during pregnancy identified that only two criteria (knowledge about transmission of mother to child according to gestational age and counseling on infection) reached 95\% compliance [33].

Like all epidemiological work, the present study proposes to present results that indicate the need for governmental actions seeking improvement. It was verified that the most incident regions for the disease, in the studied period, were the northeast and center-eastern, and that municipalities with high incidence tend to be neighbors of others with the same characteristic. The possible explanations related to the disease occurrence were that most municipalities with high incidence have an average monthly income and human development index (HDI) and an educational level between low and median [34]. Such cities require more emphatic and effective actions, for both prevention and assistance, regarding the disease in all its forms: acquired, gestational, and congenital. Such data can be reflected, in particular, by those responsible for the health of pregnant women and newborns.

The general incidence showed two clusters of positive and significant autocorrelation: a high risk for congenital syphilis, located in the Mesoregion East and Agreste, and another one of low risk comprising municipalities located predominantly in the western region of Sergipe.

\section{CONCLUSION}

During the study period, there was an increase in cases of congenital syphilis. From 2011 onwards, there was a trend toward stabilization of the disease, which appeared to have occurred due to the implementation of health surveillance services and the targeting of healthcare actions provided by public health services. The geographic distributions of the risk areas as well as the disease were heterogeneous. This can be attributed to both the breadth of the studied area and the concentration of cases of the disease in certain regions of the state of Sergipe. The analyses suggest that the goal of eliminating congenital syphilis in Sergipe is still far from being achieved.

\section{AKNOWLEDGEMENTS}

We thank Secretaria Municipal de Saúde de Aracaju and Instituto Brasileiro de Geografia (IBGE) for the support and assistence during all data collection.

\section{REFERENCES}

1. World Health Organization. Shortages of benzathine penicillin. How big is the problem? And why it matters [Internet]. [place unknown]: WHO; 2017 Dec 21 [accessed 2018 Feb 10]. Available from: http://www.who.int/reproductivehealth/shortages-benzathine-penicillin/en/ 
2. Simms I, Goh BT, French P, Wallace LA, Irvine N, Thomas DR, et al. A brief recent history of the epidemiology of congenital syphilis in the United Kingdom. Int J STD \& AIDS. 2018;29(11):1110-1119, doi: $10.1177 / 0956462418776070$

3. Taylor MM, Nurse-Findlay S, Zhang X, Hedman L, Kamb ML, Broutet N, et al. Estimating benzathine penicillin need for the treatment of pregnant women diagnosed with syphilis during antenatal care in highmorbidity countries. PloS One. 2016;11(7):01-15, doi: 10.1371/journal.pone.0159483

4. Kamb ML, Taylor MM, Ishikawa N. Rapid increases in syphilis in reproductive-aged women in Japan: a warning for other countries? Sex Transm Dis. 2018;45(3):144-146, doi: 10.1097/OLQ.0000000000000792.

5. Pires A, Oliveira D, Rocha G, Santos A. Ocorrência de sífilis congênita e os principais fatores relacionados aos índices de transmissão da doença no Brasil da atualidade - Revisão de Literatura. Rev Uningá Rev. 2014;19(1):58-64.

6. Taylor MM, Kamb M, Wu D, Hawkes S. Syphilis screening and treatment: integration with HIV services. Bull World Health Organ. 2017;95(9):610-610A, doi: 10.2471/BLT.17.200923

7. World Health Organization. Global guidance on criteria and processes for validation: elimination of mother-to-child transmission of HIV and syphilis [Internet]. Geneva (Switzerland): WHO Document Production Services; 2017 [accessed 2018 May 01]. 23 p. Available from: http://apps.who.int/iris/bitstream/handle/10665/112858/ ?sequence=1

8. Korenromp EL, Mahiané SG, Nagelkerke N, Taylor MM, Williams R, Chico RM, et al. Syphilis prevalence trends in adult women in 132 countries-estimations using the Spectrum Sexually Transmitted Infections model. Scientific Reports. 2018;8:01-10, doi: 10.1038/s41598-018-29805-9

9. Lithgow KV, Cameron CE. Vaccine development for syphilis. Expert Review of Vaccines. 2017 Jan;16(1):37-44, doi: 10.1080/14760584.2016.1203262

10. Adeyinka DA, Olakunde BO, Ozigbu CE, Agogo EA, Morka, M, Atoba T, et al. Elimination of motherto-child transmission of syphilis: Is it a reality in Nigeria by 2020? Scand J Public Health. Epub. 2017;0104, doi: 10.1177/1403494817744988

11. Carroll LN, Au AP, Detwiler LT, Fu TC, Painter IS, Abernethy NF, et al. Visualization and analytics tools for infectious disease epidemiology: a systematic review. J Biomed Inform. 2014 Oct;51:287-298, doi: 10.1016/j.jbi.2014.04.006

12. Instituto Brasileiro de Geografia e Estatística. Síntese do Estado de Sergipe em 2015 [Internet]. Rio de Janeiro: IBGE; 2017. [acesso em 2018 fev 09]. Disponível em: https://cidades.ibge.gov.br/brasil/se/pesquisa/44/47044.

13. Ministério da Saúde (BR). Secretaria de Vigilância em Saúde. Secretaria de Assistência a Saúde. Plano Operacional Redução da Transmissão Vertical do HIV e da Sífilis. Brasília: Ministério da Saúde; 2007; http://bvsms.saude.gov.br/bvs/publicacoes/plano_operacional_WEB.pdf. Accssed 10 mar 2018

14. Instituto Brasileiro de Geografia e Estatística - IBGE. Cidades: Sergipe, Rio de Janeiro [Internet]. 2017. Available from: http://cidades.ibge.gov.br/xtras/uf.php?coduf=28 [Accessed 2018 Feb 09].

15. Pereira AGL, Medronho RA, Escosteguy CC, Valencia LIO, Magalhães MAFM. Spatial distribution and socioeconomic contexto tuberculosis in Rio de Janeiro, Brazil. Rev. Saúde Pública. 2015; 49:01-08, doi: 10.1590/S0034-8910.2015049005470

16. Ministério da Saúde (BR). Secretaria de Vigilância em Saúde. Fundação Osvaldo Cruz. Sistemas de informações geográficas e análise espacial na saúde pública. Brasília: Ministério da Saúde; 2007. 148 p.

17. Druck S, Carvalho MS, Câmara G, Monteiro AVM, editors. Análise Espacial de Dados Geográficos. Planaltina (DF): Embrapa Cerrados, 2004. 208 p.

18. Santos AE, Rodrigues AL, Lopes DL. Aplicações de estimadores bayesianos empíricos para análise espacial de taxas de mortalidade. In: Proceedings of the VII Simpósio Brasileiro de GeoInfórmatica; 2005 Nov 20-23; Campos do Jordão, SP. [publisher unknown]: INPE; 2005. p. 300-309.

19. Ministério da Saúde (BR). Secretaria de Atenção à Saúde. Departamento de Atenção Básica. Atenção ao pré-natal de baixo risco. Brasília (DF): Ministério da Saúde; 2012. 318 p.

20. Saab F, Tomaz C. Prevalencia de sífilis em mujeres gestantes atendidas por el Programa de Protección a la Gestante (PPG) y reporte de aborto em el Estado de Sergipe, Brasil. Revista Salud UIS. 2016;48(2):214220.

21. Lopes IMD, Aragão JA, Lopes AD, Almeida-Santos M, Lima SO, Fonseca V, et al. Adhesion to the monitoring of newborns from VDRL positive mothers. Medical Express .2016 Nov/Dec;3(6):01-06, doi: 10.5935/medicalexpress.2016.06.02

22. Hong FC, Wu XB, Yang F, Lan LN, Guan Y, Zhang CL, et al. Risk of congenital syphilis (CS) following treatment of maternal syphilis: results of a cs control program in China. Clin Infec Dis. 2017 Aug; 65(4):588-594, doi: 10.1093/cid/cix371 
23. Soeiro CMDO, Miranda AE, Saraceni V, Santos MCD, Talhari S, Ferreira LCDL. Syphilis in pregnancy and congenital syphilis in Amazonas State, Brazil: an evaluation using database linkage. Cad Saúde Pública. 2014 Apr;30(4):715-723, doi: 10.1590/0102-311X00156312

24. Cavalcanti GMD, Nunes FMD, Alves W, Nobrega L, Amorim MM, Katz LMD. Congenital syphilis epidemiology in Alagoas-Brazil [22J]. Obstetrics \& Gynecology. 2016 May; 127(5):87S, doi: 10.1097/01.AOG.0000483791.08301.b6

25. Catunda HLO, Mendes IC, Oliveira ET, Bernardo EBR, Bezerra KC, Sousa DMN, et al. Epidemiological analysis of congenital syphilis in the state of Ceará, Brazil. DST - J Bras Doenças Sex Transm. 2013;25(1):7-12, doi: 10.5533/DST-2177-8264-201325102

26. Diário Oficial da União. Portaria no 1.884, de 11 de novembro de 1994. Publicado em: 15 Dez 1994. Seção: 1, p. 61. Ministério da Saúde. Elaboração de projetos físicos [para estabelecimentos assistenciais de saúde].

27. Arnesen L, Serruya S, Duran P. Gestational syphilis and stillbirth in the Americas: a systematic review and meta-analysis. Rev Panam Salud Publica. 2015 Jun; 37(6):422-429.

28. Kroeger KA, Sangaramoorthy T, Loosier PS, Schmidt R, Gruber D. Pathways to congenital syphilis prevention: A rapid qualitative assessment of barriers, and the public health response, in Caddo Parish, Louisiana. Sex Transm Dis. 2018 Jul;45(7):442-446, doi: 10.1097/OLQ.0000000000000787

29. Ministério da Saúde (BR). Secretaria de Vigilância em Saúde. Departamento de DST, AIDS e Hepatite Virais. Boletim Epidemiológico - HIV e AIDS. Brasília (DF): Ministério da Saúde; 2015. 95 p.

30. Marques dos Santos M, Lopes AKB, Roncalli AG, Lima KCd. Trends of syphilis in Brazil: A growth portrait of the treponemic epidemic. Plos One. 2020 Apr;15(4):e231029, doi: 10.1371/journal.pone.0231029

31. Lin JS, Eder ML, Bean SI. Screening for syphilis infection in pregnant women: updated evidence report and systematic review for the US Preventive Services Task Force. JAMA. 2018 Sep;320(9):918-925, doi: 10.1001/jama.2018.7769

32. Milanez H. Syphilis in pregnancy and congenital syphilis: Why can we not yet face this problem? Revi Bras Ginecol Obstet. 2016 Sep;38(9):425-427, doi: 10.1055/s-0036-1593603

33. Rodrigues DC, Domingues RMSM. Management of syphilis in pregnancy: Knowledge and practices of health care providers and barriers to the control of disease in Teresina, Brazil. Int J Health Plann Manage. 2018 Apr;33(2):329-344, doi: 10.1002/hpm.2463

34. Instituto de Pesquisa Econômica Aplicada. Atlas do Desenvolvimento Humano no Brasil, Brasília. 2018. http://www.atlasbrasil.org.br/ranking. Accessed 18 feb 2017 